\section{Medico-social factors associated with late presentation in women with cancer of the cervix in Northern Nigeria}

\author{
Sule Abdullahi Gaya, ${ }^{1}$ Usman Aliyu \\ Umar, ${ }^{1}$ Idris Usman Takai, ${ }^{1}$ \\ Sanusi Abubakar ${ }^{2}$ \\ ${ }^{1}$ Department of Obstetrics and \\ Gynaecology, Bayero University/Aminu \\ Kano Teaching Hospital, Kano; \\ ${ }^{2}$ Department of Community Medicine, \\ Bayero University/Aminu Kano \\ Teaching Hospital, Kano, Nigeria
}

\begin{abstract}
Cancer of the cervix is the commonest
\end{abstract} gynecological cancer and the leading cause of cancer mortality among women in Africa.Certain social behaviors have been associated with an increased risk of high-risk Human Papillomavirus (HPV) infection, which is responsible for virtually all cases of Invasive Cervical Cancer (ICC). Retrospective review of the medico-social and histo-pathologic patterns of cases of cancer of the cervix at the Gynecology Oncology Unit, Aminu Kano Teaching Hospital, Kano between January 2006 to December 2010 was conducted. The socio-demographic, medical and histological data of each patient were extracted and analyzed. A total of 91 cases of cancer of the cervix were identified. The mean age of the respondents was 48 years ( $\mathrm{SD} \pm 10.2$ years), mean parity was $7(\mathrm{SD} \pm 3.2)$ and mean age at first marriage was 15.2 years ( $\mathrm{SD} \pm 1.9$ years). Most of the patients had being married more than once in their lifetime. Majority of the women were unemployed and over half had no formal education. The commonest presenting complaint and complication respectively was vaginal bleeding $(72.5 \%)$ and anaemia (45.1\%). Most of the patient had advanced stages of the disease $(86.8 \%)$ ). Only 18 out of the 91 had undergone HIV testing, with $28 \%$ testing positive to the virus. The commonest histologic type of cervical cancer $(85.7 \%$ ) was Squamous Cell Carcinoma (SCC). There were statistically significant associations between advanced disease and age, parity and number of lifetime marriages. Patients with cancer of the cervix seen at our institution are within the reproductive age group. They are mostly grandmultiparous, have no formal education and have more than one life time marriages. They usually present with late stage disease and of SCC histologically.

\section{Introduction}

Cervical cancer is the fourth most common cancer and the fourth leading cause of cancer-related mortality in women worldwide. Approximately 570,000 new patients were estimated to be diagnosed in 2018, with 311,000 deaths projected. ${ }^{1}$ Around $85 \%$ of the global burden of the disease occurs in the less developed regions. ${ }^{1}$ Comprehensive cervical cancer control programs have been shown to result in marked reduction in the incidence and mortality among cervical cancer patients, but unfortunately comprehensive cervical cancer screening programs are generally unavailable in Nigeria. Certain types of HPV have been unequivocally established as causal factors for the disease. ${ }^{2}$ Human Papilloma Virus (HPV) type 16 accounts for $50 \%$ to $60 \%$ of cases in most countries, while HPV18 accounts for $10 \%-12 \%$ and HPV-31 and $45,4 \%-5 \%$ each. ${ }^{3,4}$ The risk factors for acquisition of HPV infection include early age at first sexual inter-course, unprotected intercourse, having multiple sexual partners, as well as a woman's partner having multiple partners. ${ }^{5,6}$ Age at First Marriage (AFM) is often used as a proxy measure for early age at first sexual intercourse, and those who engage in early sexual intercourse may also consequently become pregnant at an early age; which is also linked with an increased risk for the development of the cancer of the cervix. ${ }^{6}$

Aminu Kano Teaching Hospital, Kano is a tertiary referral health facility that is situated in Kano, Northern Nigeria. This geographic zone is known for the social practices of early marriage, frequent divorce and polygamy. The hospital has the capacity to relatively provide medical and cytological services for patients with cancer of the cervix. However, community-based palliative and screening services are poorly developed. This study is aimed at determining the social risk factors associated with cancer of the cervix at this center. This will enable identification of risk factors amongst women with cancer of the cervix who presents late so as to target thoseat risk groups early with public health and advocacy interventions to reduce their vulnerability.

\section{Materials and Methods}

This was a retrospective review of the medico-social and histopathologic patterns of cases of cancer of the cervix seen at the Gynecology Oncology Unit, Aminu Kano Teaching Hospital, Kano between January 2006 to December 2010. Only patients with
Correspondence: Usman Aliyu Umar, Department of Obstetrics and Gynaecology, Aminu Kano Teaching Hospital, Zaria Road, PMB 3452, Kano, Nigeria.

Tel.: +234.8037053599

E-mail: drusmanaliyu@yahoo.com

Key words: Cervix; cancer; social; factors.

Contributions: Concepts, data acquisition and guarantors: SGA and UAU; Design: SGA, ITU and AS; Definition of intellectual content and literature serach: SGA, UAU, ITU, AS; Data analysis: SGA and AS; Statistical analysis: SGA, ITU and AS; Manuscript preparation: SGA, UAU and AS; Manuscript editing: UAU and AS; Manuscript review: UAU, ITU, AS

Conflict of interest: The authors have no conflict of interest to declare.

Availability of data and materials: All data generated or analyzed during this study are included in this published article.

Ethics approval and consent to participate: The Ethics Committee of Aminu Kano Teaching Hospital approved this study. This was a retrospective study and data were extracted from patients file. Individual consent could not obtained because most of the patients have either died or were lost to follow up.

Received for publication: 9 August 2019.

Revision received: 28 January 2020.

Accepted for publication: 28 January 2020.

This work is licensed under a Creative Commons Attribution NonCommercial 4.0 License (CC BY-NC 4.0).

${ }^{\circ}$ Copyright: the Author(s), 2021

Licensee PAGEPress, Italy

Pyramid Journal of Medicine 2021; $4: 59$ doi:10.4081/pjm.2021.59

confirmed histological diagnosis were included in the study. Databases and medical records were reviewed to extract information on demographic and clinic-pathologic variables. Approval for the study was given by the Research and Ethics Committee of our hospital. The information extracted was feed onto a standard form designed and data were analyzed using Epi info statistical software version 3.2.2 April, 2004 (CDC Atlanta, USA). The data were presented using tables and descriptive statistics were used as absolute numbers, measures of central tendencies, and measures of dispersion. The Chi-square test was used to test significant association. A P value of less than 0.05 was considered significant. 


\section{Results}

A total of 91 cases of cancer of the cervix were identified from the register and 87 case notes were retrieved (retrieval rate of $95.6 \%$ ). Some of the variables were not documented in some of the case notes while some were obtained from the register.

The mean age of the patients was 48 years $(\mathrm{SD} \pm 10.2)$, mean parity is $7(\mathrm{SD} \pm 3.2)$ and mean age at first marriage was 15.2 years $(\mathrm{SD} \pm 1.9)$. This was shown in Table 1 and 2 respectively. Majority of the women (97.7\%) were unemployed and 77 (91.7\%) had no formal education. Most of the patients $(46.3 \%)$ had being married more than once in their lifetime and only $2(2.5 \%)$ patients were documented as smokers. Details were shown in Table 3. The commonest complication at presentation was vaginal bleeding and anaemia, which was present in $64(70.3 \%)$ patients. This was followed by obstructive uropathy in 12 $(13.2 \%)$ patients. The majority of the patienthad advanced stages of the disease $(86.8 \%)$. Only 18 out of the 91 had undergone HIV testing, with $5.5 \%$ testing positive to the virus. The commonest histological type of cervical cancer among the study group was Squamous Cell Carcinoma (SCC) constituting (85.7\%). Details were shown in Table 4.

\section{Discussion}

Cancer of the cervix is the commonest gynaecological cancer at our institution contributing up to $58.5 \%$ of all the gynaecological cancers. ${ }^{7}$ This study was undertaken to determine medico-social factors associated with cancer of the cervix in our environment. The study revealed that cancer of the cervix in our environment is a disease of women in the reproductive age group and in middle aged women in particular. The majority of the patients married at an early age, have high parity, have no formal education, have married more than once and presented with features of late disease. These findings are consistent with findings by Adewuyi et al. and Oguntayo et al. at Zaria $^{8,9}$ and in many other developing countries. ${ }^{10}$ Early age at marriage, high parity and polygamy have been found to be strongly associated with high risk HPV acquisition. ${ }^{11}$ Cervical cancer is mostly $(99 \%)$ linked to genital infection with the human papillomaviruses. ${ }^{12}$ These factors are still very prevalent in our environment despite laudable government efforts on girl child education and family planning. Although these efforts are primarily aimed at reducing maternal mortality, they also have an added advantage of curbing the menace of cancer of the cervix. Very young girls, usually virgins, are given out for marriage to much older men, some with three or more wives. ${ }^{13,14}$ This may increase the likelihood of a girl acquiring HPV infection at first intercourse with her husband. Polygamy is reported to increase the risk of cervical cancer two-fold and the risk increases with increasing number of wives. ${ }^{15,16}$ High parity, as found in this study, is also a recognized independent risk factor, together with HPV-related co-factor for the development of cervical cancer. ${ }^{17,18}$

To change behavior and personal practices permanently, it is necessary to give proper information and encourage logical attitudes through health education programs. Cancer education is based on the premise that susceptibility to diseases can be linked to certain integral determinants

Table 1. Age distribution of women with cancer of the cervix.

\begin{tabular}{lcc}
\hline Age (Years) & Frequency & Percentage (\%) \\
$20-29$ & 2 & 2.2 \\
$30-39$ & 10 & 11.0 \\
\hline $40-49$ & 49 & 53.8 \\
$50-59$ & 15 & 16.5 \\
\hline $60-69$ & 12 & 13.2 \\
$70-74$ & 2 & 2.2 \\
\hline $80-89$ & 1 & 1.1 \\
Total & 91 & 100 \\
\hline
\end{tabular}

Mean: 48 SD: 10.2.

Table 2. Distribution of parity among patients with cancer of the cervix at AKTH.

\begin{tabular}{lcc} 
Parity & Frequency & Percentage (\%) \\
$1-4$ & 21 & 23.1 \\
$5+$ & 70 & 76.9 \\
\hline Total & 91 & 100 \\
\hline
\end{tabular}

Mean Parity $=7 \mathrm{SD}=3.2$.

Table 3. Social characteristics.

\begin{tabular}{llcc} 
Social characteristics & & Frequency & $\%$ \\
Educational status $\mathrm{n}=84^{*}$ & None/Quranic & 77 & 91.7 \\
& Primary & 3 & 3.6 \\
& Secondary & 4 & 4.7 \\
Employment status $\mathrm{n}=88^{*}$ & Employed & 2 & 2.3 \\
& Unemployed & 86 & 97.7 \\
\hline Smoker status $\mathrm{n}=80^{*}$ & Smoker & 2 & 2.5 \\
& Non Smoker & 78 & 97.5 \\
Marital status N=91 & Married & 67 & 73.6 \\
& Divorced & 5 & 5.5 \\
& Widowed & 19 & 20.9 \\
\hline No. of lifetime marriages $\mathrm{N}=82^{*}$ & 1 & 44 & 53.7 \\
& 2 & 21 & 25.6 \\
& $>2$ & 17 & 20.7 \\
\hline
\end{tabular}

*Missing values are due to incomplete data. such as awareness and attitudes on related values and beliefs, which are known as predisposing factors. ${ }^{18}$ Generally, cancer education programs range from promotion of cancer awareness to promotion of early behaviors. $^{18}$

Worldwide, women of low socio-economic status have a greater risk of developing cervical cancer. Cervical cancer is often referred to as a disease of poverty and poverty is endemic in sub-Saharan Africa. Poverty is also a very important barrier to prevention and treatment of this disease. Al formal education. Cigarette smoking is a known social risk factor for developing cancer of the cervix ${ }^{19}$ but only about $2 \%$ of our patients ever smoked cigarettes. This is similar to the findings by Oguntayo and 
Table 4. Medical features.

\begin{tabular}{|c|c|c|c|}
\hline Medical parameters & & Frequency & $\%$ \\
\hline Type of cancer $n=87^{*}$ & $\begin{array}{l}\text { Squamous cell carcinoma } \\
\text { Adenocarcinoma } \\
\text { Transitional cell carcinomma }\end{array}$ & $\begin{array}{l}75 \\
10 \\
2\end{array}$ & $\begin{array}{l}88.2 \\
11.6 \\
2.2\end{array}$ \\
\hline History of STI $n=91$ & $\begin{array}{l}\text { Positive past history of STI } \\
\text { No past history of STI } \\
\text { Not stated }\end{array}$ & $\begin{array}{c}5 \\
74 \\
12 \\
\end{array}$ & $\begin{array}{l}5.5 \\
81.3 \\
13.2\end{array}$ \\
\hline HIV status of respondents $n=91$ & $\begin{array}{l}\text { Positive } \\
\text { Negative } \\
\text { Not tested }\end{array}$ & $\begin{array}{c}5 \\
13 \\
73\end{array}$ & $\begin{array}{c}5.5 \\
14.3 \\
80.2\end{array}$ \\
\hline FIGO staging of cervical cancer $n=91$ & $\begin{array}{l}\text { Stage 1 } \\
\text { Stage 2a } \\
\text { Stage 2b } \\
\text { Stage 3 } \\
\text { Stage } 4 \\
\text { Not staged }\end{array}$ & $\begin{array}{c}1 \\
6 \\
21 \\
32 \\
26 \\
5\end{array}$ & $\begin{array}{c}1.1 \\
6.6 \\
23.1 \\
35.2 \\
28.5 \\
5.5 \\
\end{array}$ \\
\hline History of contraceptive use $n=79^{*}$ & $\begin{array}{l}\text { Used contraceptive } \\
\text { Did not use contraceptive }\end{array}$ & $\begin{array}{l}10 \\
69\end{array}$ & $\begin{array}{l}12.7 \\
87.3\end{array}$ \\
\hline Complications at presentation $n=91$ & $\begin{array}{l}\text { Vaginal bleeding with anaemia } \\
\text { Bladder mass } \\
\text { Obstructive uropathy } \\
\text { Urinary incontinence } \\
\text { Stroke } \\
\text { Renal failure } \\
\text { Rectal bleeding } \\
\text { No complications }\end{array}$ & $\begin{array}{c}64 \\
1 \\
12 \\
2 \\
1 \\
8 \\
1 \\
2\end{array}$ & $\begin{array}{l}70.3 \\
1.1 \\
13.2 \\
2.2 \\
1.1 \\
8.8 \\
1.1 \\
2.2\end{array}$ \\
\hline
\end{tabular}

*Missing values are due to incomplete data.

colegues at Zaria, ${ }^{8}$ a close location to Kano and this is explained by the fact thatsmoking among women is a taboo in the local culture. Only $5.5 \%$ of our patient had a history suggestive of STI as against $>30 \%$ in the Zaria study by Adewuyi et al. ${ }^{7}$ Similarly only few (about 20\%) were tested for HIV and only 5 out of the 18 that had the test were positive. Studies have shown that HIV-infected women with cervical cancer are more likely to have advanced disease at presentation and to have a higher recurrence rate than non-HIV-infected women and cervical intraepithelial neoplasia occurs more frequently in women with HIV infection. ${ }^{20}$

Most of our patients presented with features of late stage disease which is similar to other findings in this region. This has been cited to be as a result of prevailing poverty, poor educational level and lack of awareness. ${ }^{8}$ Other factors that limit patient attendance are the cost of medical services, especially for diagnosis and treatment of cancers, and the bias against women and children, whose health issues are not considered a priority by their immediate families.

Over the years several attempts have been made to relate prognosis of carcinoma of the cervix with histological parameters. The majority of the cancers were SCC of the well differentiated, large cell keratinizing variety in accordance with other local and international studies. ${ }^{21}$ There was however a relatively large proportion of adenocarcinoma (11.0\%) in this study when com- pared to earlier accounts of the disease in Nigerian women, ${ }^{22}$ but the findings are in keeping with the global trend of increasing proportion of adenocarcinomas in cervical cancers in developed countries. ${ }^{21}$ Amongst black women, it has been suggested that increasing age, frequent marriages and high parity raise the probability of developing adenocarcinoma of the cervix. ${ }^{21}$ These factors are known to be prevalent in our environment andthese changing patterns histologic cervical cancer types may also have prognostic significance considering that Adenocarcinoma (ADC) has poorer prognosis when compared with Squamous Cell Carcinoma (SCC) of the same stage.

\section{Conclusions}

Patients with cancer of the cervix seen at our institution are within the reproductive age group. They are mostly grandmultiparous with no formal education and have more than one life time marriages. They usually present with late stage squamous cell carcinoma. There is need to increase awareness among women on cervical cancer and provide mechanism for early screening and diagnosis.

\section{References}

1. Ferlay J, Colombet M, Soerjomataram I, et al. Estimating the global cancer incidence and mortality in 2018: GLOBOCAN sources and methods. Int J Cancer 2019;144:1941-53.

2. Munoz N, Bosch FX, Castellsaque X, et al. Against which human papilloma virus types shall we vaccinate and screen? The international perspective. Int J Cancer 2004;111:278-285.

3. Bosch FX, Sanjose S. Human papilloma virus and cervical cancer - Burden and Assessment of causality. J Natl cancer Inst 2003;31:3-13

4. International Agency for Research on Cancer (IARC). Monographs on the Evaluation of Carcinogenic Risks to Humans, Volume 90. Human Papillomaviruses. Lyon (France): IARC; 2007.

5. IARC MonogrEval Carcinogen Risks Hum. Human Papillomaviruses 2007. International Agency for Research on Cancer: Lyon; Vol. 90.

6. Gaya SA, YakasaiIA, Muhammad AZ, et al. Cancer of the cervix in unscreened West African women. J Basic Clin Reprod Sci 2012;1:44-8.

7. Adewuyi SA, Shittu SO, Rafindadi AH. Socio-demographic and clinic-pathologic characterization of cervical cancers in northern Nigeria. Eur J Gynaec Oncol 2008;29:61-4.

8. Oguntayo AO, Zayyan M, Kolawole $\mathrm{AOD}$, et al. Cancer of the cervix in Zaria, Northern Nigeria. eCancer 2011;5:219.

9. Ijaya MA, Aboyeji AP, Olatinwo AWO, Buhari MO. Clinico-pathological presentation of primary cervical cancer seen in Ilorin, Nigeria. Niger $\mathrm{J}$ Surg Res 2002;4:89-92.

10. Bayo S, Bosch FX, de SanjoseS, et al. Risk factors of invasive cervical cancer in Mali. Int J Epidemiol 2002;31:202-9.

11. Louie KS, de Sanjose S, Diaz M, et al. Early age at first sexual intercourse and early pregnancy are risk factors for cervical cancer in developing countries. $\mathrm{Br}$ J Cancer 2009;100: 1191-7.

12. Palefsky JM, Holly EA. Molecular virology and epidemiology of human papillomavirus and cervical cancer. Cancer Epidemiol Biomarkers Prevent 1998;4:425-8.

13. Palacio-Mejía LS, Range-Gomez G, Hernandez Avila M, et al. Cervical cancer, a disease of poverty: mortality difference between urban and rural areas in Mexico. Salud Pública de México 2003;45:S315-25.

14. Nour NM. Health Consequences of Child Marriage in Africa. Emerg Infect Dis 2006;12:1644-9.

15. Anorlu RI. Cervical cancer: the subSaharan African perspective. Reprod 
Health Matters 2008;16:32:41-9.

16. Hildesheim A, Herrero R, Castle PE, et al. HPV co-factors related to the development of cervical cancer: results from a population-based study in Costa Rica. Br J Cancer 2001;84:1219-26.

17. Munoz N, Franceschi S, Bosetti C, et al. Role of parity and human papillomavirus in cervical cancer. The IARC multicentre case-control study. Lancet 2002;359:1093-101.
18. Denny L. The prevention of cervical cancer in the developing world. BJOG 2005;112:1204-12.

19. Fonseca-Moutinho JA. Smoking and cervical cancer. ISRN Obstetr Gynecol 2011:847684.

20. Mapanga W, Girdler-Brown B, Feresu $\mathrm{SA}$, et al. Prevention of cervical cancer in HIV-seropositive women from developing countries through cervical cancer screening: a systematic review. Syst
Rev 2018;7:198.

21. Smith Ho, Tiffany MF, Qualls $\mathrm{Cr}$ et al. The rising incidence of adenocarcinoma relative to squamous-cell carcinoma of the uterine cervix in the United States-A 24 year population-based study. Gyn Oncol 2000;78:97-105.

22. Mandong BM, Ujah IA, Uguru VE. Clinico-pathological study of carcinoma of the cervix in Jos, Nigeria. Nig Med Pract 1997;34:76-9. 